6. Звід принципів захисту всіх осіб, що піддаються затриманню чи ув'язненню у будьякій формі, схвалений резолюцією № 43/173 Генеральної Асамблеї OOH 9 грудня 1988 р. URL: http://zakon.rada.gov.ua/laws/show/995_206 (дата звернення 03.03.2020).

УДК 343.14

DOI https://doi.org/10.32844/2618-1258.2019.5-2.45

КРЕТ Г.P.

\title{
СИСТЕМА МІЖНАРОДНИХ СТАНДАРТІВ ФОРМУВАННЯ ДОСТОВІРНИХ ДОКАЗІВ
}

Стаття присвячена розкриттю напрацьованих ЄСПЛ міжнародних стандартів достовірності доказів як їх процесуальної властивості. Вказується на загальний підхід ЄСПЛ до оцінки доказів, відповідно до якого вона входить до повноважень національних судів. Звертається увага на обов'язок ЄСПЛ враховувати під час встановлення справедливості провадження у справі питання надання заявнику можливості спростувати достовірність доказів і заперечити проти їх використання та щодо якості доказів і того, чи породжують обставини, за яких вони були здобуті, будь-яких сумнівів щодо їхньої надійності й точності.

Розкривається коло випадків, за яких ЄСПЛ звертається до питання про обгрунтованість здійсненої національними судами оцінки доказів із точки зору їх достовірності. Досліджуються правові позиції ЄСПЛ щодо забезпечення національними судами права обвинуваченого на справедливий судовий розгляд у разі використання свідчень відсутніх свідків, свідчень зі слів інших осіб, свідчень анонімних свідків. Розкриваються правові позиції ССПЛ щодо забезпечення вказаного права у контексті забезпечення національними судами можливості обвинуваченого оскаржити висновки експерта, подані стороною обвинувачення.

Наводяться правові позиції ЄСПЛ щодо неприпустимості використання національними судами для обгрунтування судових рішень свідчень учасників кримінального провадження (зокрема визнавальних свідчень обвинуваченого, свідчень свідків, потерпілих), отриманих за обставин, що свідчать про застосування щодо них катування або нелюдського чи такого, що принижує гідність, поводження.

Викладаються правові позиції ЄСПЛ щодо використання національними судами свідчень учасників кримінального провадження, отриманих за обставин, що вказують на можливу недобровільність їх надання, у тому числі й у випадках подальшої відмови учасників кримінального провадження від таких свідчень або їх зміни. Розкриваються правові позиції ССПЛ щодо неприпустимості обгрунтування національними судами ухвалених ними судових рішень на основі доказів, суперечливість яких не була усунута в ході судового розгляду. На основі проведеного дослідження узагальнюється система міжнародних стандартів формування достовірних доказів, напрацьованих у практиці ЄСПЛ.

Ключові слова: стандарти доказування, міжнародні стандарти доказування, достовірність доказів, стандарти формування достовірних доказів, Європейський суд з прав людини.

The article is devoded to the disclosure international standards for the reliability of evidences as their procedural property, formed by the ECHR. The ECHR's general approach to the assessment of evidences under which it is an authority of national courts is indicated. Attention is drawn to the obligation of the ECHR to take into account, when

(C) КРЕТ Г.Р. - кандидат юридичних наук, доцент, суддя (Касаційний кримінальний суд у складі Верховного Суду) 
establishing the fairness of the proceedings in general, the issue of allowing the applicant to refute the reliability of the evidences and to object to its use and the quality of the evidences and whether the circumstances in which it was obtained give rise to any doubt for their reliability and accuracy.

The range of cases in which the ECHR addresses the question of the validity of the assessment of evidences accomplished by national courts in terms of their reliability is revealed. The ECHR's legal position on ensuring by national courts the right of the accused to a fair trial in the cases of using the testimony of absent witnesses, testimony from other persons, testimony of anonymous witnesses are investigated. The ECHR's legal position on ensuring this right is disclosed in the context of ensuring by national courts the opportunity of the accused to dispute the expert's opinion provided by the prosecution side are revealed.

The ECHR's legal positions on the inadmissibility of the use by national courts to substantiate the judgments the testimony of participants of criminal proceedings (in particular, the recognition testimony of the accused, the testimony of witnesses and victims) obtained in circumstances that testify about use to them torture or inhuman or degrading treatment or punishment are indicated. The ECHR's legal positions on the use by national courts of testimony of participants of criminal proceedings obtained in circumstances that indicate the possible involuntary of their giving, including the cases of further refusal of participants of criminal proceedings from such testimony or their changes are outlined.

The ECHR's legal positions on the inadmissibility of the justification by national courts of their judgments on the basis of evidences the controversy of which was not eliminated during the trial art revealed. On the basis of the conducted research, the system of international standards for formation of reliable evidences, developed in the practice of ECHR, is generalized.

Key words: standards of proof, international standards of proof, reliability of evidences, standards for formation of reliable evidences, European Court of Human Rights.

Вступ. Визначені у нормах вітчизняного кримінального процесуального закону вимоги, які стосуються достовірності доказів, грунтуються на напрацьованих у практиці Європейського суду $з$ прав людини (далі - ЄСПЛ) міжнародних стандартах формування достовірних доказів. Останні сформовані ЄСПЛ в ході надання ним оцінки дотримання права на справедливий судовий розгляд, закріпленого ст. 6 Конвенції про захист прав людини і основоположних свобод від 04.11.1950, ратифікованої Законом України від 17.07.1997 № 475/97-ВР (далі - Свропейська конвенція від 04.11.1950). 3 урахуванням динамічності практики ЄСПЛ міжнародні стандарти формування достовірних доказів зазнають постійного розвитку та удосконалення, що свідчить про існування їх системи.

Правові позиції ЄСПЛ щодо достовірності доказів та ії встановлення національними судами були предметом наукових досліджень А.М. Безносюка, Л.П. Брич, В.В. Вапнярчука, І.В. Гловюк, О.М. Дроздова, В.А. Завтура, М.А. Погорецького та інших вітчизняних і зарубіжних вчених. Водночас виокремленню сформованих ЄСПЛ стандартів формування достовірних доказів присвячена недостатня увага, що зумовлює необхідність звернення до дослідження напрацьованої ним у цій частині практики.

Постановка завдання. Метою статті є розкриття на основі дослідження практики ЄСПЛ системи міжнародних стандартів формування достовірних доказів.

Результати дослідження. Вказуючи на віднесення оцінки доказів, у тому числі з точки зору їх допустимості, до повноважень національних судів, ЄСПЛ водночас звертає увагу на власний обов'язок врахувати під час встановлення справедливості провадження у справі питання надання заявнику можливості спростувати достовірність доказів і заперечити проти їх використання та щодо якості доказів і того, чи породжують обставини, за яких вони були здобуті, будьяких сумнівів щодо їхньої надійності й точності (п.п. 273 і 274 рішення від 21.04.2011 у справі «Нечипорук і Йонкало проти України») [1]. При цьому у низці випадків ЄСПЛ звертається до питання про обгрунтованість здійсненої національними судами оцінки доказів із точки зору їх достовірності.

По-перше, до оцінки стверджуваного заявником порушення права на справедливий судовий розгляд внаслідок позбавлення його можливості перевірити достовірність доказів ЄСПЛ 
звертається у випадках, коли національними судами використані свідчення показання відсутніх свідків і свідчення зі слів інших осіб, у зв'язку з чим ним здійснюється одночасна перевірка допустимості та достовірності доказів.

Так, ЄСПЛ зауважує, що визнання допустимим доказом свідчень відсутніх свідків призводить до потенційно невигідних умов для обвинуваченого, який під час судового розгляду кримінальної справи повинен мати можливість оскаржити доказ проти нього. Зокрема, він повинен мати можливість перевірити точність і достовірність свідчень свідків шляхом їх допиту в усній формі у його присутності або під час надання свідчень свідком або на далі певній стадії провадження (п. 75 рішення від 30.01.2018 у справі «Боєць проти України») [2].

Допит свідків обвинувачення під час судового розгляду є вагомою гарантією забезпечення прав обвинуваченого, особливо у випадках самостійного здійснення ним захисту, а 3 іншої сторони - невід'ємним елементом встановлення судом достовірності доказів. Як вказує ЄСПЛ, заявник не отримав допомоги адвоката в ході розслідування, а саме на цьому етапі були отримані такі основні докази, як наприклад протокол очної ставки та його визнання. У цьому зв'язку мало вирішальне значення, щоб свідків обвинувачення допитав суд першої інстанції, оскільки тільки цей суд міг зблизька ефективно оцінити їхню поведінку і достовірність їхньої версії подій (п. 90 рішення від 19.06.2003 у справі “Hulki Güneş v. Turkey”) [3].

Припускаючи можливість використання національними судами свідчень відсутніх свідків і свідчень зі слів інших осіб, під час встановлення факту дотримання національними судами ст. 6 Європейської конвенції від 04.11.1950 ЄСПЛ застосовує триступеневий тест, на останньому етапі якого він має надати відповідь на питання про те, чи були достатні врівноважуючі фактори, у тому числі важливі процесуальні гарантії, які компенсують складності, 3 якими зіткнулася сторона захисту в результаті прийняття як доказу неперевірених показань, і забезпечують справедливість судового розгляду, що оцінюється (п.П. 119-147 рішення від 15.12.2011 у справі “Al-Khawaja and Tahery v. the United Kingdom”, п. 107 рішення від 15.12.2015 у справі "Schatschaschwili v. Germany") [4; 5].

Розкриваючи коло врівноважуючих факторів, ЄСПЛ до них відносить заходи, здатні забезпечити справедливу та належну оцінку достовірності такого доказу, і вказує, що вирішення вказаного питання дозволить обгрунтувати засудження на підставі такого доказу лише за умови, що він є достатньо достовірним з урахуванням його важливості для справи (п. 75 рішення від 30.01.2018 у справі «Боєць проти України») [2]. Одним із таких врівноважуючих заходів ЄСПЛ визнає застосування у ході проведення допиту свідка на попередніх етапах провадження відеозапису. Зокрема, на його думку, якби щонайменше був відеозапис допиту свідка М., то це дозволило б суду, сторонам обвинувачення та захисту в судовому засіданні спостерігати за поведінкою свідка під час допиту та скласти власне уявлення щодо достовірності його або її показань (п. 92 рішення від 30.01.2018 у справі «Боєць проти України») [2].

Встановлення ЄСПЛ відсутності достатніх врівноважуючих заходів є негативною відповіддю на завершальне питання зазначеного триступеневого тесту, на використання свідчень відсутніх свідків і свідчень зі слів інших осіб, що призводить до визнання ним порушення права на справедливий судовий розгляд.

Як вказує ЄСПЛ, нездатність органів влади України докласти всіх розумних зусиль для забезпечення явки свідка М., важливість його свідчень для засудження заявниці та відсутність достатніх урівноважуючих заходів, які дозволили б провести справедливу та належну оцінку достовірності неперевірених свідчень, змушують суд дійти висновку, що відсутність у заявниці на будь-якій стадії провадження можливості допитати М. або вимагати, щоб їі допитали, загалом зробила судовий розгляд несправедливим. Було порушення пункту 1 та підпункту “d” пункту 3 статті 6 Конвенції (п.п. 94 і 95 рішення від 30.01.2018 у справі «Боєць проти України») [2].

Поряд із цим оцінка стверджуваному заявником порушенню права на справедливий судовий розгляд внаслідок позбавлення його можливості перевірити достовірність доказів надається ЄСПЛ у випадках, коли національними судами в ухвалених ними судових рішеннях використовувалися свідчення анонімних свідків.

Вказуючи на винятковість випадків використання національними судами свідчення анонімних свідків (п. 56 рішення від 23.04.1997 у справі "Van Mechelen and Others v. the Netherlands") [6], ЄСПЛ у процесі встановлення факту дотримання національними судами ст. 6 Європейської конвенції від 04.11.1950 звертає увагу на необхідність забезпечення співмірності інтересів сторін обвинувачення та захисту, врівноваження можливостей останньої за допомогою судової процедури і неможливість використання свідчень анонімних свідків як єдиного або вирішального 
доказу (п.п. 70, 72 і 76 рішення від 26.03.1996 у справі “Doorson v. the Netherlands”, п.п. 53-55 рішення від 23.04.1997 у справі “Van Mechelen and Others v. the Netherlands") [6; 7].

У своїй практиці ЄСПЛ констатує дотримання національними судами ст. 6 Європейської конвенції від 04.11.1950 у разі забезпечення ними можливості оскарження стороною захисту під час судового розгляду достовірності свідчень анонімних свідків обвинувачення (п.п. 73-76 рішення від 26.03.1996 у справі “Doorson v. the Netherlands”) [7]. У випадках, коли національні суди не забезпечили стороні захисту можливості оскаржити достовірність свідчень анонімних свідків обвинувачення, ЄСПЛ вказує на порушення ними п. 1 і пп. "d" п. 3 ст. 6 Свропейської конвенції від 04.11.1950 (п.п. 49 і 50 рішення від 15.06.1992 у справі "Lüdi v Switzerland”, п.п. 59-65 рішення від 23.04.1997 у справі "Van Mechelen and Others v. the Netherlands", п.п. 33 і 34 рішення від 28.03.2002 у справі “Birutis and Others v Lithuania") [6; 8; 9].

Крім того, до оцінки стверджуваного заявником порушення права на справедливий судовий розгляд внаслідок позбавлення його можливості перевірити достовірність доказів ЄСПЛ звертається у випадках, коли національні суди позбавили заявника можливості подати альтернативні висновки експерта з метою спростування висновків експерта, поданих стороною обвинувачення. Як зауважує ЄСПЛ, у контексті експертних доказів правила допустимості не повинні позбавляти сторону захисту можливості їх ефективного оскарження, зокрема шляхом подання або отримання альтернативних звітів чи висновків. За певних обставин відмова у прийнятті альтернативної експертизи як доказу може вважатися порушенням п. 1 ст. 6 Конвенції (п. 169 рішення від 27.03.2014 у справі "Matytsina v. Russia") [10], оскільки може бути складно оскаржити висновок експерта без допомоги іншого експерта у відповідній сфері (п. 187 рішення від 25.07.2013 у справі "Khodorkovskiy and Lebedev v. Russia") [11].

Поряд із можливістю подання стороною захисту альтернативного висновку експерта, спрямованого на оскарження висновку експерта, поданого стороною обвинувачення, ЄСПЛ звертає увагу на можливість перевірки достовірності останнього за допомогою допиту експерта. Зокрема, сторона захисту має право оскаржувати не лише експертний висновок, але й достовірність тих, хто його складав, шляхом допиту (п. 711 рішення від 25.07.2013 у справі “Khodorkovskiy and Lebedev v. Russia") [11].

У низці справ ЄСПЛ вказує на неприпустимість використання національними судами для обгрунтування судових рішень свідчень учасників кримінального провадження, отриманих за обставин, що свідчать про застосування до них катування або нелюдського чи такого, що принижує гідність, поводження чи вказують на можливу недобровільність їх надання (зокрема визнавальних свідчень обвинуваченого, свідчень свідків, потерпілих), у тому числі й у випадках подальшої відмови учасників кримінального провадження від таких свідчень або їх зміни.

Що стосується визнавальних свідчень обвинуваченого, отриманих за обставин, які свідчать про застосування щодо нього катування або нелюдського чи такого, що принижує гідність, поводження, то ЄСПЛ звертає увагу на те, що право не свідчити проти самого себе передбачає, що сторона обвинувачення у кримінальній справі прагне довести свою версію у справі проти обвинуваченого, не вдаючись до доказів, отриманих шляхом примусу або придушення волі обвинуваченого. Визнавальні свідчення, отримані на порушення ст. 3, вважаються недостовірними. Крім того, у кримінальному провадженні вони часто стають безпосереднім приводом для жорсткого поводження. Використання таких свідчень для визнання людини винною $є$ несумісним із гарантіями, передбаченими ст. 6 Конвенції (п.п. 81 і 82 рішення від 09.02.2016 у справі "Shlychkov v. Russia") [12].

Вказуючи на неприпустимість використання національними судами свідчень свідків, отриманих за обставин, що свідчать про застосування щодо них катування або нелюдського чи такого, що принижує гідність, поводження, ЄСПЛ з урахуванням конкретних обставин справи зауважує, що заявника примусили зізнатися, а свідків Т. та О. (які на час отримання їх свідчень під час досудового розслідування та судового розгляду були військовослужбовцями) - дати свідчення, які підтверджують провину заявника.

Свідчення, здобуті внаслідок такого поводження, національні суди фактично використали як докази у кримінальному процесі проти заявника. Це було зроблено попри те, що факт жорстокого поводження вже був встановлений у паралельному провадженні в справі, порушеній проти відповідних співробітників поліції. У зв'язку з цим суд зазначив, що національні суди обгрунтовували використання визнань тим, що заявник зізнався слідчому, а не працівникам поліції, які з ним жорстоко поводилися, що свідок Т. підтвердив своє попереднє зізнання на очній ставці 11.08.1999, і що обидва свідки - Т. та О. - дали аналогічні свідчення під час слухань 26.10.1999 у Сюнікському окружному суді. 
Факт їх подальшого перебування на військовій службі посилював побоювання та впливав на їх свідчення, що підтверджує суттєва зміна характеру останніх після демобілізації. Отже, достовірність свідчень, наданих у той період, мала б викликати серйозні сумніви, а тому наводити їх на обгрунтування достовірності свідчень, наданих під катуванням, було не слід. У світлі викладених вище міркувань суд дійшов висновку, що використання таких доказів, хоч би який вплив ці свідчення, здобуті під тортурами, мали на результати кримінального провадження у справі заявника, перетворило розгляд його справи на несправедливий (п.п. 64-66 рішення від 28.06.2007 у справі "Harutyunyan v. Armenia") [13].

Звертаючи увагу на неприпустимість використання національними судами свідчень свідків, отриманих за обставин, що вказують на можливу недобровільність їх надання, ЄСПЛ зауважує, що у справі, яка розглядається, національні суди визнали заявника винним, спираючись на свідчення К., якого вони вважали ключовим свідком у справі. Під час судового розгляду заявник стверджував, що К. дав свідчення проти нього під тиском працівників поліції, але К. заперечував це в суді. На перший погляд всіх процесуальних гарантій було дотримано. Проте, беручи до уваги конкретні обставини цієї справи, суд вважав, що заявнику не надали адекватної можливості оскаржити доказову силу цих свідчень.

Суд зауважив, що заявник послався на конкретні факти і документи, які свідчать про те, що на момент допиту пана К. (водія таксі, який в минулому не мав судимості і не був причетним до інших правопорушень, які згадуються в матеріалах справи) слідчим його було затримано в адміністративному порядку у зв'язку з правопорушенням у сфері обігу наркотичних засобів. Як стверджував заявник (і це підтвердив Хмельницький міськрайонний суд у своєму рішенні від 05.05.2005), саме в цей період часу свідчення пана К. змінилися не на користь заявника.

Заявник також надав суду першої інстанції аудіозапис розмови, яку він мав із паном К. і під час якої той нібито визнав, що звів на нього наклеп під тиском поліції. Суд визнав, що реакція як суду першої інстанції, так і Верховного Суду на ці аргументи є вражаюче недостатньою та неадекватною. Повертаючись до обставин справи, яка розглядається, суд зазначив, що суди вирішили надати значення обвинувальним свідченням пана К., проігнорувавши при цьому конкретні та відповідні факти, здатні поставити під сумнів їх достовірність і точність; так і не було переконливо встановлено, що пан К. давав ці свідчення добровільно, тоді як його заяви в суді про їх добровільність могли бути результатом подальшого його залякування; свідчення пана К. змінилися не на користь заявника з часу його допиту, що збігався 3 часом його затримання. 3 огляду на викладене вище суд дійшов висновку, що мало місце порушення п. 1 ст. 6 Конвенції (п.п. 275-281 рішення від 21.04.2011 у справі «Нечипорук і Йонкало проти України») [1].

У низці справ ЄСПЛ звертає увагу на обов'язок національних судів усунути суперечливість між доказами, зокрема між свідченнями свідків між собою та 3 іншими доказами. Так, він вказує, що неузгодженості між власними свідченнями свідків, наданими в різні періоди часу, так само як і серйозні неузгодженості між різними видами доказів, наданими стороною обвинувачення, призводять до серйозних підстав для оскарження довіри до свідка та доказової сили його свідчень.

Цей вид оскарження становить заперечення, здатне вплинути на оцінку фактичних обставин справи, які грунтувалися на цих доказах, і на результат судового розгляду (п. 206 рішення від 26.07.2011 у справі "Huseyn and Others v. Azerbaijan") [14]. Неусунення національними судами суперечливості між доказами за відсутності інших доказів винуватості обвинуваченого у вчиненні кримінального правопорушення призводить до констатації ЄСПЛ порушення ними права на справедливий суд, закріпленого п. 1 ст. 6 Європейської конвенції від 04.11.1950. Так, у п.п. 62-74 рішення від 13.11.2018 у справі «Чжан проти України» він погодився з аргументом заявника, що ключовим доказом, на підставі якого він був засуджений за вчинення вбивства, були свідчення друзів потерпілого Са., Су. та Д., які в різні періоди часу були непослідовними.

Суд вказав, що у цій справі сторона захисту у своїх неодноразово висловлених протягом всього провадження запереченнях вказувала на зазначені неузгодженості та суперечності. Крім того, національні суди у своїх рішеннях самі визнали їх серйозними недоліками, неодноразово даючи вказівки повернути справу на додаткове досудове слідство. Проте суд зазначив, що зрештою жодних спроб розглянути ці питання не було. Хоча неоскаржувані недоліки в свідченнях свідків вимагали більш ретельної оцінки національними судами, вони без будь-яких пояснень вирішили не ставити під сумнів достовірність цих доказів, не кажучи вже про тлумачення будьяких сумнівів на користь обвинуваченого. 
Суд звернув увагу і на той факт, що, крім цих неузгодженостей у свідченнях свідків обвинувачення, жодних речових або інших доказів проти заявника не було. Крім того, на користь сторони захисту були численні свідчення студентів-китайців, а один з них у певний момент навіть зізнався, що випадково поранив одного з українців. Суд зазначив, що національні суди усіх трьох інстанцій не дали жодної оцінки особливо актуальним і важливим зауваженням заявника щодо серйозних недоліків у свідченнях свідків сторони обвинувачення і стверджуваної незаконності та свавільності виключення з матеріалів справи усіх свідків сторони захисту. Зазначених міркувань достатньо для висновку суду, що кримінальне провадження проти заявника загалом становило порушення його права на справедливий суд за п. 1 ст. 6 Конвенції [15].

Висновки. Загалом у практиці ЄСПЛ сформовані такі міжнародні стандарти формування достовірних доказів: 1) оцінка доказів із точки зору їх достовірності є обов'язком національних судів, які повинні враховувати конкретні та відповідні факти, здатні поставити під сумнів достовірність і точність доказів; 2) національні суди зобов'язані забезпечити стороні захисту можливість оскаржити докази сторони обвинувачення з метою перевірки їх достовірності (зокрема шляхом допиту свідків обвинувачення, виклику та допиту свідків захисту, подання висновків експерта, складених за дорученням сторони захисту); 3) свідчення відсутніх свідків і свідчення зі слів інших осіб підлягають використанню національними судами виключно за наявності достатніх врівноважуючих факторів, у тому числі заходів, здатних забезпечити справедливу та належну оцінку достовірності такого доказу; 4) свідчення анонімних свідків підлягають використанню національними судами виключно за умови забезпечення співмірності інтересів сторін обвинувачення та захисту, врівноваження можливостей останньої за допомогою судової процедури і не можуть бути єдиним або вирішальним доказом, покладеним в основу обвинувального вироку; 5) визнавальні свідчення обвинуваченого, свідчення свідків і потерпілих, отримані за обставин, які свідчать про застосування щодо нього катування або нелюдського чи такого, що принижує гідність, поводження, є недостовірними; 6) за наявності суперечливості у доказах національні суди зобов'язані ії усунути; 7) в разі виникнення сумнівів щодо достовірності доказу зростає необхідність підтвердження його за допомогою інших доказів.

\section{Список використаних джерел:}

1. Справа «Нечипорук і Йонкало проти України» : Рішення Європейського суду з прав людини від 21.04.2011. URL: https://zakon.rada.gov.ua/laws/show/974_683.

2. Справа «Боєць проти України» : Рішення Європейського Суду з прав людини від 30.01.2018. URL: https://zakon.rada.gov.ua/laws/show/974_c64.

3. Case of Hulki Güneş v. Turkey : Judgment of the European Court of Human Rights from 19 June 2003. URL: http://echr.ketse.com/doc/28490.95-en-20030619/view/.

4. Case of Al-Khawaja and Tahery v. the United Kingdom: Judgment of the European Court of Human Rights from 15 December 2011. URL: http://hudoc.echr.coe.int/eng?i=001-108072.

5. Case of Schatschaschwili v. Germany : Judgment of the European Court of Human Rights from 15 December 2015. URL: http://hudoc.echr.coe.int/eng?i=001-159566.

6. Case of Van Mechelen and Others v. the Netherlands: Judgment of the European Court of Human Rights from 23 April 1997. URL: http://hudoc.echr.coe.int/eng?i=001-58030.

7. Case of Doorson v. the Netherlands : Judgment of the European Court of Human Rights from 26 March 1996. URL: https://www.legal-tools.org/doc/4d8820/pdf/.

8. Case of Lüdi v. Switzerland : Judgment of the European Court of Human Rights from 15 June

1992. URL: https://hudoc.echr.coe.int/eng?i=001-57784.

9. Case of Birutis and Others v Lithuania : Judgment of the European Court of Human Rights from 28 March 2002. URL: https://hudoc.echr.coe.int/eng?i=001-60395.

10. Case of Matytsina v. Russia : Judgment of the European Court of Human Rights from 27 March 2014. URL: http://hudoc.echr.coe.int/fre?i=001-141950.

11. Case of Khodorkovskiy and Lebedev v. Russia : Judgment of the European Court of Human Rights from 25 July 2013. URL: http://hudoc.echr.coe.int/eng?i=001-122697.

12. Case of Shlychkov v. Russia : Judgment of the European Court of Human Rights from 9 February 2016. URL: http://hudoc.echr.coe.int/eng?i=001-160417.

13. Case of Harutyunyan v. Armenia : Judgment of the European Court of Human Rights from 28 June 2007. URL: http://hudoc.echr.coe.int/eng?i=001-81352/.

14. Case of Huseyn and Others v. Azerbaijan : Judgment of the European Court of Human Rights from 26 July 2011. URL: http://echr.ketse.com/doc/35485.05-35680.05-36085.05-45553.05en-20110726/view/. 
15. Справа «Чжан проти України» : Рішення Європейського Суду з прав людини від 13.11.2018. URL: https://zakon.rada.gov.ua/laws/show/974_d21.

УДК 343.163

DOI https://doi.org/10.32844/2618-1258.2019.5-2.46

ПЕТРУК О.М.

\title{
ПРАВОВЕ РЕГУЛЮВАННЯ ВІДШКОДУВАННЯ ШКОДИ \\ ВІД КРИМІНАЛЬНОГО ПРАВОПОРУШЕННЯ У МІЖНАРОДНО-ПРАВОВИХ ДОКУМЕНТАХ ОРГАНІЗАЦІЇ ОБ'СДНАНИХ НАЦЙ
}

\begin{abstract}
У статті досліджуються деякі питання, які стосуються забезпечення відшкодування шкоди від кримінального правопорушення та перенесення акценту із захисту прав правопорушника на пріоритетний напрям захисту жертв правопорушення, громадських інтересів, які передбачені у міжнародних документах універсального характеру. Міжнародною спільнотою розроблено документи, що охоплюють ключові питання кримінального судочинства із визначенням переліку міжнародних стандартів. Вони стосуються забезпечення прав людини, організації і діяльності органів досудового розслідування, прокуратури й суду, а також відшкодування шкоди. Розроблення та прийняття за основу міжнародних стандартів належить Організації Об’єднаних Націй.

Наголошено, що міжнародно-правовими документами передбачено низку інститутів та правових механізмів поряд з інститутом цивільного позову в кримінальному провадженні, які пропонується застосовувати для відшкодування шкоди від кримінального правопорушення.

Документи приймає Організація Об'єднаних Націй і надсилає їх на забезпечення інтересів потерпілих від злочинів. Саме діючи таким чином від імені міжнародної спільноти, Генасамблея ООН своєю Резолюцією 60/147 від 16 грудня 2005 року прийняла Основні принципи і керівні положення, які стосуються права на захист і відшкодування шкоди для жертв порушень міжнародних норм у галузі забезпечення прав людини і серйозних порушень міжнародного гуманітарного права. Державам рекомендовано брати їх до уваги, сприяти дотриманню і доводити до відома персоналу виконавчих органів урядів, особливо співробітників правоохоронних органів, збройних сил і служб безпеки, законодавчих органів, судових органів, потерпілих та їх представників, захисників, представників засобів масової інформації та громадськості.

Основні принципи і керівні положення не створюють нових міжнародних або внутрішньодержавних правових зобов'язань, а визначають механізми, форми, процедури та методи їх здійснення, що існують відповідно до міжнародних норм у галузі забезпечення прав людини в кримінальному провадженні та міжнародному гуманітарному праві, які доповнюють один одного, хоча і різні за предметом правового регулювання.
\end{abstract}

Ключові слова: права людини, відшкодування шкоди, кримінальне провадження, Організаџія Об’єднаних Наџій, декларачія.

The article explores some issues related to ensuring compensation for damages from a criminal offense and shifting the focus on the protection of the offender's rights to the priority area of protection of the victims of the offense, public interests, which are envisaged in international documents of universal nature. Documents covering key issues ніх справ)

(C) ПЕТРУК О.М. - ад’юнкт кафедри кримінального процесу (Національна академія внутріш- 